ことができる。このため, 水の使用量も最低限におさえることが できる。捕足された粉塵は, 水循環装置のタンク内にスラッジと して沈殿し, 水は泥水に強いモノポンプにより循環する。

(6) タンクの洗净

蓄積したスラッジは，大きなドレンバルブから取り出す。この バルブを開き, 水面が下がるとフロートバルブにより水が自動的 に流れて、スラッジを完全に流し出す。
今後, 坑内環境改善の要望が; 高まつてくるに従い, このよう な小型高性能集塵機が，必要欠くべからざるものになるであろう。 このE N G A R T 集塵機は，それらの=ーズに充分応えるもので あると確信する。なお，現在国内でも，土木トンネル，造船所等 で, 合計10台程本集塵機が活翟しており, 高い評価を得ている。 関係各位のご検討，ご指導をお願いする次第である。

\title{
7. む び
}

[一 般 講 演]

\section{（17）炭鉱における深部移行によるコストアップの定量化について}

\section{1. ま え がき}

石炭鉱業において生産現場の深部移行に伴つて起こる問題は, 第一には保安上の問題である。つまり(1)盤王，山はね，(2)ガス突 出, (3)自然発火, (4)高温度等である。今一つはコストアップの問題 である。

石炭の生産現場は一般の生産工場と異なり, 採掘切羽が深部か あるいは奥部に移行するため，一般的な物価，人件費アップの外 に特別なコストアップが発生する。これを梁部移行によるコスト アップと称しているが, 従来この值について定量化, あるいは計 数化についてはあまり行なわれていない。

前者の保安上の問題およびこの対策費としてのコストアップに ついては一部を除き論じないこととし，一般的な“深部移行によ るコストアップ”について筆者らの考察の経過と一つの試案につ いて記述する。

\section{2. 深部移行によるコストアップの定義}

深部移行によるコストアップについては，次の二つの場合を考 える必要がある。

(A) 深部移行によるコストアップ

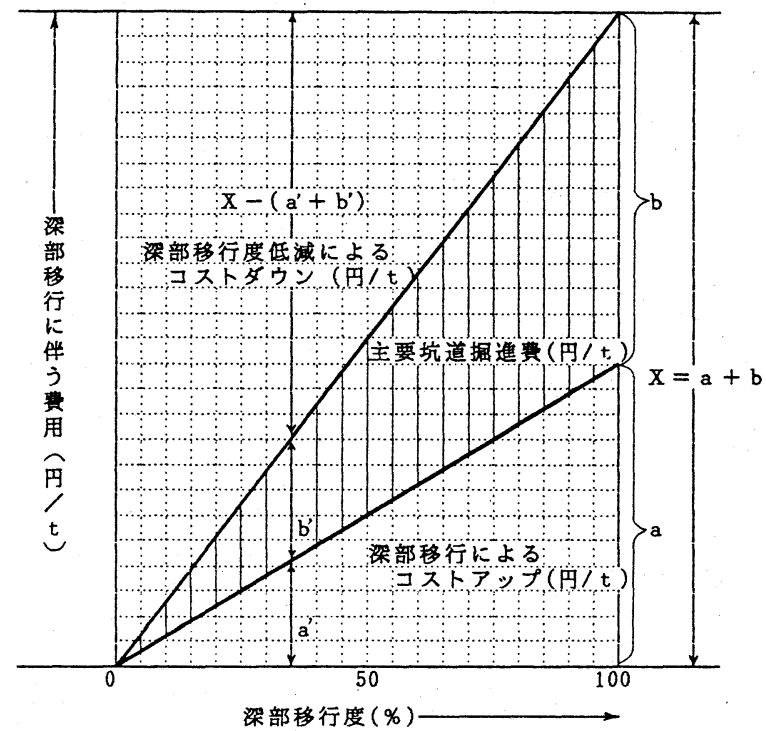

第1図 深部移行度とコストアップの関係
(B) 深部移行の度合が低減される場合のコストダウン

前者の場合, 深部移行により増加する費用が問題となるが，後 者の場合は, 深部移行の度合により発生する費用の大小がコスト ダウンの尺度となる。

この(A) と(B)項の関連，仕組みを第 1 図に示す。(A)の場合は $a$ の 值，(B)の場合は $X-\left(a^{\prime}+b^{\prime}\right)$ の值が問題となる。

\section{3. 定量化のための試算}

\section{$3 \cdot 1$ 試算の方式および経緯}

試算の方式として次の二つの方式をとつた。

（1） 過去の実績分析による（試算一1)

（2）理論計算および実績積上げによる（試算-2）

最初に(1)の方式によりある程度の傾向または解析の系口が得ら れるのではなからうかと期待したが, 全くそれらしいものは得ら れなかつた。次の(2)の方式により概略試算ができた。

\section{$3 \cdot 2$ 過去の実績による分析 (試算一 1$)$}

採掘深度と切羽原価および坑口原価との関連について実績デー タにより分析を行なつた。

（1）切羽深度と切羽原価 昭和57年度に操業した11の採炭切羽 について, その深度と切羽原価の関係を分析したが, 全く相関性 はなかつた。

(2) 採掘深度と坑口原価 昭和 51 年度以降 57 年度までの年度別 採掘平均深度と坑口原価の実績を第 2 図に示す。なお坑口原価は 毎年のエスカレーションを加味して 57 年度ベースに換算して試算 をした。結果は(1)と同様深度と坑口原価の関連性は全く認められ なかつた。

参考までにこの場合, 資料数 $=7$ でありその相関係数は次のと おりである。

$\gamma_{1}=0.4084 \quad$ (原炭 $\mathrm{t}$ 当り原価と深度の相関係数)

$\gamma_{2}=-0.3502$ (精炭 $\mathrm{t}$ 当り原価と深度の相関係数)

(3) 分析 過去の実績データ分析からは, 深度がコストにど のように影響するかについての手掛りは全く得られなかつた。し かし，これは原価を左右する要因が深度以外に数多くあつて当然 の帰結であると考えられると同時に，逆説的に次のことがいえる のではなからうか。

（i）深くなればコストが高くなるということは，深度以外のす べての条件が同一の場合にのみいえることである。

(ii) 深度のコストへの影響度は外の要因に比して小さいのでは なかろうか, 現実に切羽原価を左右するものは, 出炭量, 生産性, 


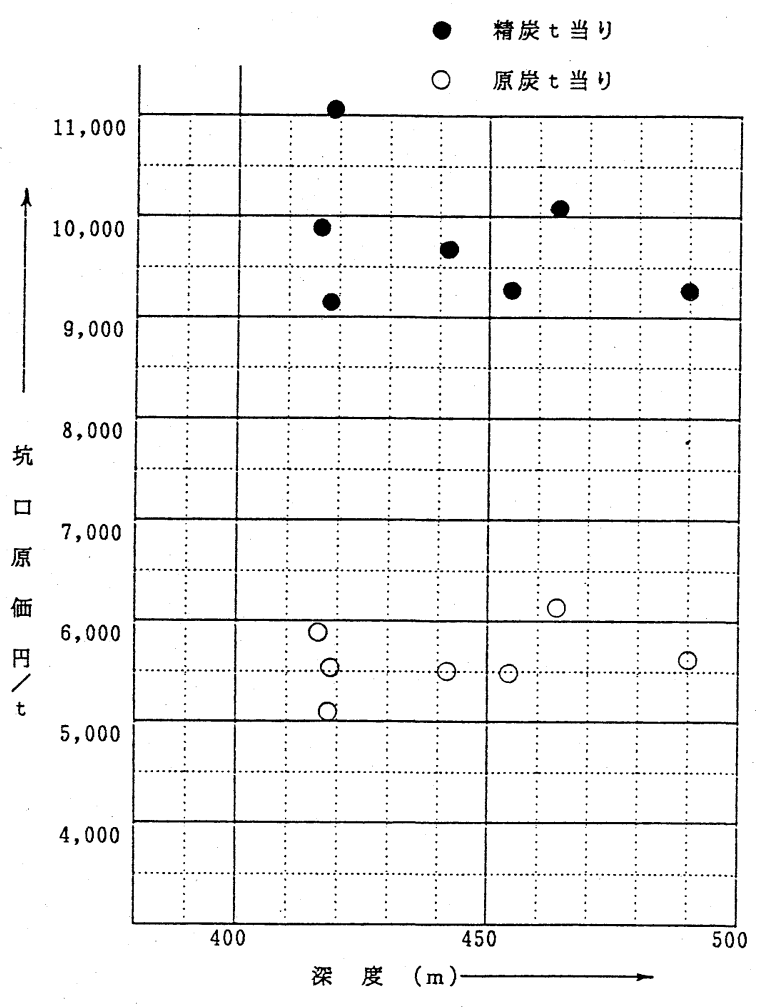

第 2 図 深度と坑口原価

採炭方式および対象炭層等である。特に対象炭層のウェイトが最 も大である。

(iii) 現実には，深部移行によるコストアップをセーブするため 技術および労働態様の面での機械化，合理化が行なわれている。 等々の理由によるものと思われる。

\section{4. 理論計算および実績値積上げ計算 ( 試算-2 $)$}

\section{$4 \cdot 1$ 試算の項目および方式}

試算の項目およびその方式を第 1 表に示す。

上表の試算項目を $\mathrm{A}, \mathrm{B}$ に分けた理由は，A項は一般的に増加す る費用であり，B 項は深部移行のために必要な掘進費用である。 また試算方式については，理論計算，仮説の設定による計算およ び実績の積上げによる算定の 3 つの方式によつた。

\section{$4 \cdot 2$ 電力費 $(A-1)$}

採掘区域の深部移行，奥部化に伴い電力費が堌加するが，その 主体をなすものは運搬, 通気, 排水である。

（1）石炭運搬電力費稼行正面を同一とし傾斜方向(雓)に逐 次移行するものとし，かつ 1 本の集団ベルトにより揚炭するもの として, 出炭量別, 深度別 (距離別) 運搬電力費の理論計算を行 なつた。その結果深度 $100 \mathrm{~m}$ 当り (斜距離 $1,000 \mathrm{~m}$ ) の増加電力費 および $\mathrm{t}$ 当りの増加電力費を算出した（炭層傾斜 $=6$ 度）。

（2）通気電力費 (1)項同様採掘区域の横の広がりを同一とし て傾斜方向(縦)の坑道延長に伴う通気動力費を試算した。この場 合, 所要風量は実績データにより推定しかつ $3 \sim 4$ 分流によるも のとした。また消費負圧の計算には，ある一定の坑道断面に経済 通気速度の概念を入れて試算した。その結果として深度 $100 \mathrm{~m}$ (斜 距離 $1,000 \mathrm{~m}$ ) 当り, $\mathrm{t}$ 当り增加電力費を算出した。

（3）排水電力費 運搬, 通気と同じく傾斜方向のみを想定し 排水量別, 深度別の年間所要電力費を算出し, 最後に深度 $100 \mathrm{~m}$ 当り, $\mathrm{t}$ 当り増加電力費を算出した。

以上の電力費はそれぞれについて, 試算結果と実績とを照合チ
第1表 試算項目と方式

\begin{tabular}{|c|c|c|}
\hline 記 号 & 項 & 式 \\
\hline$A-1$ & 電力费 (運搬、通気、排水) & 理墖計算 \\
\hline$A-2$ & 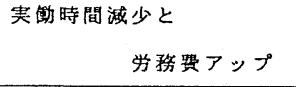 & $\begin{array}{l}\text { 理論計算 } \\
\text { (時間と人員数) }\end{array}$ \\
\hline$A-3$ & 支保费 & $\begin{array}{l}\text { 仮説の設定 } \\
\text { (伜理および伜間) }\end{array}$ \\
\hline$A-4$ & 坑道維持、拡大費、 & $\begin{array}{l}\text { 奏績值 } \\
\text { (主要坑道の菗大仕綵実綪) }\end{array}$ \\
\hline$A-5$ & 主要設硔の賽却费 & 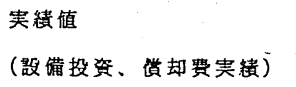 \\
\hline$A-6$ & 主要設備の保全费 & 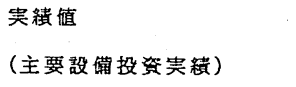 \\
\hline B & 主要坑道の掘道费 & 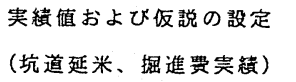 \\
\hline
\end{tabular}

ェックを行なつた。

$4 \cdot 3$ 労働時間の減少とコストアップ $(A-2)$

深部移行に伴う個人の実働時間の減少に対して, これに相応す る人員を増員するものとしてコストアップを試算した。

試算では距離 $1,000 \mathrm{~m}$ 当りの損失時間を人員数に換算かつその 年間労務費を算定した。この值から年間の移行度と出炭から $\mathrm{t}$ 当 り労務費を算出した。

$4 \cdot 4$ 支保費 $(A-3)$

深部移行に伴う支保費の増大についてこれを計数化することは， 過去のデータからあるいは論理的にも困難である。それは支保そ のものが画一的に深度の関数として決定されるものでないからで ある。本試算では最近の実績データを使用し，ある一定の仮説の もとで深度 $100 \mathrm{~m}$ 当りの支保費の増加額を算定した。それは

（1）支保費用を鋼枠強度（枠種）と支保密度（枠間）からコス 卜指数として表わした。

（2）深度増に伴いある一定の仮説のもとで枠種，枠間を変化さ せ，深度別鋼枠コスト指数を算出した。この場合現行深度に対す る枠種分布をべースとした。

（3）実績鋼枠費を用い，深度差（たと光ば $100 \mathrm{~m}$ 当り）による 支保増加額を算出した。もちろんこの値は仮説の決め方により変 ることはいうまでもない。

\section{$4 \cdot 5$ 坑道維持および拡大費用 $(A-4)$}

深部移行に伴つて維持坑道長が増加する。この坑道維持費が増 加すると同時に, 通気対策として主要坑道の拡大仕繰費用が増大 する。これらの費用の試算のため, 過去の実績を使用した。これ ら工事の実績延メートルは年間約 $5,000 \sim 6,000 \mathrm{~m}$ で，ほぼ毎年の 増加維持坑道長に相応する。また工事費は年間 $5 \sim 6$ 億円である。

\section{$4 \cdot 6$ 主要機械設備の償却費}

深部移行に伴い主要機械設備の投資が必要となる。この設備費 のみをみれば, 主要坑道の掘進費と同じく増加する費用とはなら ない。しかし償却費として計上することからその年度の償却費が 増加する。償却費はある年数でなくなるが，その場合更新の費用 がかかるとして試算をした。

この費用については過去の実績データを使用した。最近の実績 では, 深部移行に伴う設備投資は年間平均 $7 \sim 10$ 億円程度であり, その償却費は約 4 億円程度である。

$4 \cdot 7$ 主要機械設備の保全費 $(A-6)$

主要機械設備の堌加に伴いこれらの保全費が増大する。この費 
用試算のため過去の保全費実績を調査したが，この目的に合うよ うな分類はされていないため, 主要機械設備の保全費そのものは, 抽出できなかつた。そのため前節の主要機械設備費をもとに約 10 \%の保全費がかかるものとして, 年間 $0.7 \sim 1.0$ 億円の保全費增と した。

\section{$4 \cdot 8$ 主要坑道の掘進費 (B)}

採掘区域の移行に伴つて主要坑道および採炭準備坑道の掘進が 必要となる。このうち主要坑道については, 深部移行に伴つて増 加する費用とはならない。たとえば深度がー $300 \mathrm{~m}$ から- $500 \mathrm{~m}$ に 変化したとしても同一出炭という前提では, 主要坑道の掘進長は 一般的に差異ないからである。しかし深部移行度の増減に対して は移行に伴つて発生する費用として計上されねばならない（第 1 図参照）。一方採炭準備坑道は，深部移行の有無にかかわらず一 定の出炭確保のため必要な坑道であつて計算の対象とはならない。 主要坑道の所要掘進長については, ある仮定のもとで試算し, 掘進費については実績単価を使用した。

（1）昭和 48 年以降 58 年度までの岩石掘進長は, 1,000 t 当り 1.3 $\sim 4.2 \mathrm{~m}$ と相当の幅があつて, 現行フィルドである一定の出炭確 保のため, 必要な岩石掘進について実績からは求め得なかつた。

（2）従つて現行フィルドに合わせて試算条件を設定し, 深部 移行度別所要岩石掘進長を算出し, 更に岩石掘進実績単価から年 間の掘進費用および $\mathrm{t}$ 当り費用を算出した。

なお試算条件として, 稼行正面および水平基幹坑道のスパンを きめ,この採掘ブロックに必要なる岩石掘進長をきめた。

\section{5. 深部移行度}

深部移行度は年間の移行距離を, 斜距離または垂直距離で表わ す。そしてこの移行の度合によりコストアップの大小がきまるこ とはいうまでもない。

昭和51年度以降最近までの実績では, 比較的浅部の採掘等によ り平均採掘深度は必ずしも増加していない。従つて実績からは求 め難く，ある条件下で試算をした。その条件を次に示す。
a. 稼行正面 $=8 \mathrm{~km}$
b. 水平基幹坑道スパソ $=3 \mathrm{~km}$

( 1 ブロック面積 $=8 \times 3=24 \mathrm{~km}^{2}$ )

c. 炭量密度 $=4,5,6 \mathrm{t} / \mathrm{m}^{2}$

d. 実収率 $=20 \sim 35 \%$

この諸条件から実収炭量を求め, 更に出炭量別の年間移行度を 算出した。試算例を第 2 表に示す。
第 2 表 生産量, 実収炭量別深部移項度

\begin{tabular}{|c|c|c|c|c|c|c|}
\hline \multirow{2}{*}{$\begin{array}{c}\text { 実収炭量 } \\
\text { (万 } t \text { ) }\end{array}$} & \multicolumn{2}{|c|}{ 200万 $\mathrm{t}$ /年 } & \multicolumn{2}{|c|}{250 万 $\mathrm{t}$ /年 } & \multicolumn{2}{|c|}{300 万 $\mathrm{t}$ /年 } \\
\hline & $\begin{array}{c}\text { 期 間 } \\
\text { (年) }\end{array}$ & $\begin{array}{l}\text { 䔟行度 } \\
\text { (₫/年) }\end{array}$ & $\begin{array}{c}\text { 期 間 } \\
\text { (年) }\end{array}$ & $\begin{array}{l}\text { 移行度 } \\
\text { (四/年) }\end{array}$ & $\begin{array}{c}\text { 期 間 } \\
\text { (年) }\end{array}$ & $\begin{array}{l}\text { 移行度 } \\
\text { (m/年) }\end{array}$ \\
\hline 2,000 & 10.0 & 300 & 8.0 & 375 & 6.7 & 448 \\
\hline 2,500 & 12.5 & 240 & 10.0 & 300 & 8.3 & 361 \\
\hline 3,000 & 15.0 & 200 & 12.0 & 250 & 10.0 & 300 \\
\hline 3,500 & 17.5 & 172 & 14.0 & 214 & 11.7 & 256 \\
\hline 4,000 & 20.0 & 150 & 16.0 & 188 & 13.3 & 226 \\
\hline
\end{tabular}

\section{6. 深部移行によるコストアップの試算}

以上の $\mathrm{A}$ 項, $\mathrm{B}$ 項および深部移行度から, 深部移行の度合いに より，またその目的によりコストの増減が試算できる。

（1）深部移行度が同一の場合 増加するコストとしてA項を 試算することにより, 年間 $\mathrm{t}$ 当りどの程度コストアップするのか $(x \mathrm{H} / \mathrm{t})$ ，あるいは坑口原価に対して年間何\%程度アップするか がわかる。

（2）深部移行度が増減する場合 生産規模の変化とか, 同一 出炭量ではあるがたとえば実収率アップ等により深部移行度の低 減を図つた場合等, その内容に合わしての試算が可能となる。

$$
\text { 7. む び }
$$

深部移行に伴うコストアップの定量化について思考の経緯を含 めて試算の一方式について記述した。

理論計算, 仮説の設定による試算および実績の積上げ等, 項目 毎に種々の方式を用い, 一貫性はないが, 本テーマに対しての概 值は求め得ることができたと思う。

またこのコストアップの值およびその構成内容等は今後の長期 計画, あるいは本テーマに関連しての特定プロジェクトの成果の 評価などに充分使用することが可能であると考える。

試算の方式に一定のルールがある筈もなく, 炭鉱それぞれの特 性からその炭鉱にふさわしい試算の方式があるのではなからうか。 その意味で, この報文が何等かの参考になれば筆者として誠に幸 いに思う。

終りに, 本テーマ解明のため数多くの提言とデータの提示など ご協力いただいた山元の各位に厚く感謝の意を表明する次第であ る。

\section{[一 般 講 演 $]$}

\section{（18） 人エダイヤモンドビットによるボーリング作業能率の向上}

\section{1. はじめに}

砂川炭鉱は昭和 28 年より先進ガス抜きボーリングを実施してい るが, 深部移行が進むに伴い増加する作業量を消化するため作業 能率の向上には殊更留意してきた。

特に砂川炭鉱安定化計画を実施に移している現在，いかにして より少ない人員で必要作業量を消化するかが, ボーリング作業に 課せられた課題である。

この度, 人エダイヤモンドビットの使用によりこの課題に取組
み好結果を得ることができた。すなわち，一昨年 8 月ボーリング 作業の硬岩対策として人エダイヤモンドビットをテスト使用した。 その結果が好成績であつたので, 逐次使用数を増しかつ適用範囲 を広げ現在では岩石ボーリングの約 $60 \%$ を人エダイヤモンドビッ トで実施し，成果を上げている。

ここに，その経過と実績について報告する。

\section{2. 砂川炭鉱におけるボーリング作業の実態}

当炭鉱のボーリング作業は, 岩石ボーリングの占める割合が大 